\title{
The effect of culture media on the number and bioactivity of marine invertebrates associated fungi
}

\author{
AGUS TRIANTO ${ }^{1,2, \bullet}$, OCKY KARNA RADJASA ${ }^{1,3}$, MADA TRIANDALA SIBERO ${ }^{1,4}$, AGUS SABDONO ${ }^{1,3}$, \\ DWI HARY ANTI ${ }^{1}$, WA ODE MARDHIYYAH ZILULLAH ${ }^{1}$, ANNISA RORO SY ANINDYTA ${ }^{1}$, \\ MUHAMMAD SYAIFUDIEN BAHRY ${ }^{2}$, PRASTYO ABI WIDIANANTO ${ }^{3}$, MUHAMAD HELMI ${ }^{5}$, \\ HARYO DWITO ARMONO ${ }^{6}$, SUPRIADI ${ }^{7}$, YASUHIRO IGARASHI ${ }^{8}$ \\ ${ }^{1}$ Department of Marine Science, Faculty of Fisheries and Marine Sciences, Universitas Diponegoro. Jl. Prof. Soedharto, S.H. Tembalang, Semarang \\ 50275. Central Java, Indonesia. Tel.: +62-24-7474698, `email: agustrianto.undip@ gmail.com. \\ ${ }^{2}$ Natural Product Laboratory, Centre for Research and Services, Universitas Diponegoro. J1. Prof. Soedharto, S.H. Tembalang, Semarang 50275. Central \\ Java, Indonesia \\ ${ }^{3}$ Tropical Marine Biodiversity Laboratory, Faculty of Fisheries and Marine Sciences, Universitas Diponegoro. J1. Prof. Soedharto, S.H. Tembalang, \\ Semarang 50275. Central Java, Indonesia \\ ${ }^{4}$ Department of Oceanography, Faculty of Fisheries and Marine Science, Faculty of Fisheries and Marine Sciences, Universitas Diponegoro. J1. Prof. \\ Soedharto, S.H. Tembalang, Semarang 50275. Central Java, Indonesia \\ ${ }^{5}$ Center of Marine Biotechnology Studies, Marine Science Techno Park (MSTP), Universitas Diponegoro. Teluk Awur Campus. Jl. Undip, Jepara 59427, \\ Central Java, Indonesia \\ ${ }^{6}$ Faculty of Marine Technology, Institut Teknologi Surabaya. J1. Raya ITS, Keputih, Sukolilo, Surabaya 60111, East Java, Indonesia \\ ${ }^{7}$ Faculty of Marine Science and Fisheries, Universitas Hasanuddin. Jl. Perintis Kemerdekaan Km. 10, Makassar 90245, South Sulawesi, Indonesia \\ ${ }^{8}$ Biotechnology Research Center, Toyama Prefectural University. 5180 Kurokawa, Imizu, Toyama 939-0398, Japan
}

Manuscript received: 19 December 2019. Revision accepted: 30 December 2019.

\begin{abstract}
Trianto A, Radjasa OK, Sibero MT, Sabdono A, Haryanti D, Zilullah WOM, Syanindyta AR, Bahry MS, Widiananto PA, Helmi M, Armono HD, Supriadi, Igarashi Y. 2020. The effect of culture media on the number and bioactivity of marine invertebrates associated fungi. Biodiversitas 21: 407-412. Marine ecosystem is rich with microorganisms such as bacteria and fungi either as freeliving or in association with macro-organisms. Marine invertebrates provide suitable habitats for fungi by supplying space, food, and other chemicals stuff that in some cases is a reciprocal relationship or called mutualism symbiotic. Some marine invertebrates have interesting activities that are useful for human life such as anticancer, antifungal, and antibacterial. Many reports indicated that the fungal growth and their production of bioactive compounds were highly affected by the media or nutrition. In order to understand the effect of media on the number and bioactivity of the isolates, we collected the samples of marine invertebrates from two locations in Makassar. Invertebrate specimens were collected by hand during SCUBA diving at 3-10 m depths. The fungi were isolated by tapping method either on potato dextrose agar (PDA) or poor marine agar (PMA). The samples were collected from the Samalona water as much as 16 specimens that provided 30 and 18 fungal isolates on PDA and PMA, respectively, while, from the Barrang Cadi water, a total 14 specimens were collected to provide 12 and 3 isolates on PDA and PMA, respectively. All fungi from PMA inhibited the $V$. harveyi, $V$. vulnificus, and $V$. parahaemolyticus with weak, medium, and strong activities, while, the isolates from PDA were mostly not active against the Vibrios. Based on the molecular analyses, the active isolates were identified as Aspergillus flavus, A. oryzae, A. aculeatus, Talaromyces minioluteus, Hypocrea jecorina, Gliomastix murorum, Myrothecium inundatum, and Curvularia avinis. In conclusion, the isolates from PMA showed higher potential as source of antivibrio substances.
\end{abstract}

Keywords: Sponge, tunicate, nudibranch, fungi, vibrio

\section{INTRODUCTION}

Marine microorganisms are widely studied as source of secondary metabolites that are useful for human life (Carroll et al. 2019; Pham et al. 2019). Among all marine microorganisms, fungi get a special concern due to its productivity in producing novel bioactive compounds (Tarman et al. 2011; Zhou et al. 2014; Lindequist 2016) One of bioactive compounds from marine fungi is Plinabulin which is isolated from Aspergillus sp. It is being investigated by Food and Drug Administration (FDA) to be applied for cancer therapy (Pereira 2019). Furthermore, plenty of bioactive compounds from marine fungi are isolated every year in order to obtain new drugs for human health (Imhoff 2016; Lindequist 2016). Marine fungi have also been reported that produce antimicrobial compounds such as isaridins, cristatumins, and stachyins (Xu et al. 2015). The capability to producing novel bioactive compounds leads to massive isolation of marine fungi from various hosts and locations.

Indonesia's marine ecosystems are considered to host enormous untapped marine fungi. Marine fungi are commonly found as a free-swimming organism or living in association with other micro-organisms such as sponge, coral, and tunicate (Gradinger 2016; Grossart et al. 2016; Hassett and Chen et al. 2018; Sibero et al. 2018; Xu et al. 2018). Therefore, Spermonde Archipelago in Makassar, South Sulawesi, Indonesia is suggested as one of prospective locations that harbor marine fungi due to its diversity of marine invertebrates (De Voogd et al. 2006; 
Litaay et al. 2018). Several genera such as Aspergillus, Cladosporium, Daldinia, Eutypella, Fusarium, Lasiodiplodia, Trichoderma were previously isolated as invertebrate-associated fungi from Indonesia (Tarman et al. 2012; Trianto et al. 2018; Sibero et al. 2019). These fungi also performed decent antibacterial activity against pathogenic bacteria.

In addition, most of studies were applied in a richnutrient medium to isolate marine fungi such as potato dextrose agar (PDA), Sabouraud dextrose agar (SDA), cornmeal agar (CMA), malt extract agar (MEA) and yeast malt agar (YMA) (Trianto et al. 2017; Chen et al. 2018; Sibero et al. 2018). The influence of isolation medium to the diversity of cultivable-marine fungi had been reported, however, study of the influence of isolation medium to the antibacterial activity of the cultivable-marine fungi is rarely done. Therefore, the purpose of this study was to investigate the effect of standard and poor media on the number and anti-vibrio activity of cultivable invertebrateassociated fungi from Spermonde Islands in Makassar, Indonesia.

\section{MATERIALS AND METHODS}

\section{Sample materials}

Marine invertebrates such as sponge, coral, tunicate, and nudibranch were collected around Samalona and
Barrang Caddi, Spermonde Islands, Makassar, Indonesia (Figure 1) by SCUBA at 3-10 m depth. All samples were documented under and above water. Samples were kept inside a sterilized zip lock then transferred for fungal isolations.

\section{Fungal isolation}

A rich nutrient medium, potato dextrose agar (PDA, (HiMedia) and a poor marine agar (PMA) were used to isolate invertebrate-associated fungi. Poor nutrient agar (PMA) has consisted of agar and marine water without any additional nutrients. Fungal isolation was performed according to Sibero et al. (2019) using tapping method. Samples were cleaned using a running sterilized marine water and alcohol $70 \%$. The surface of samples was discarded to remove surface contamination. Further, samples were cut into approx. $1 \mathrm{~cm} \times 1 \mathrm{~cm}$ and put onto isolation media then incubated at room temperature $\left(27^{\circ} \mathrm{C}\right)$ until fungal growth was identified. During isolation, environmental control was prepared using PDA and PMA. All mycelia growing surrounding samples were transferred onto new media as a pure culture. Each fungus from isolation media was compared to the fungi from environmental control and the distinct isolates were confirmed as associated fungi then used for the further steps.

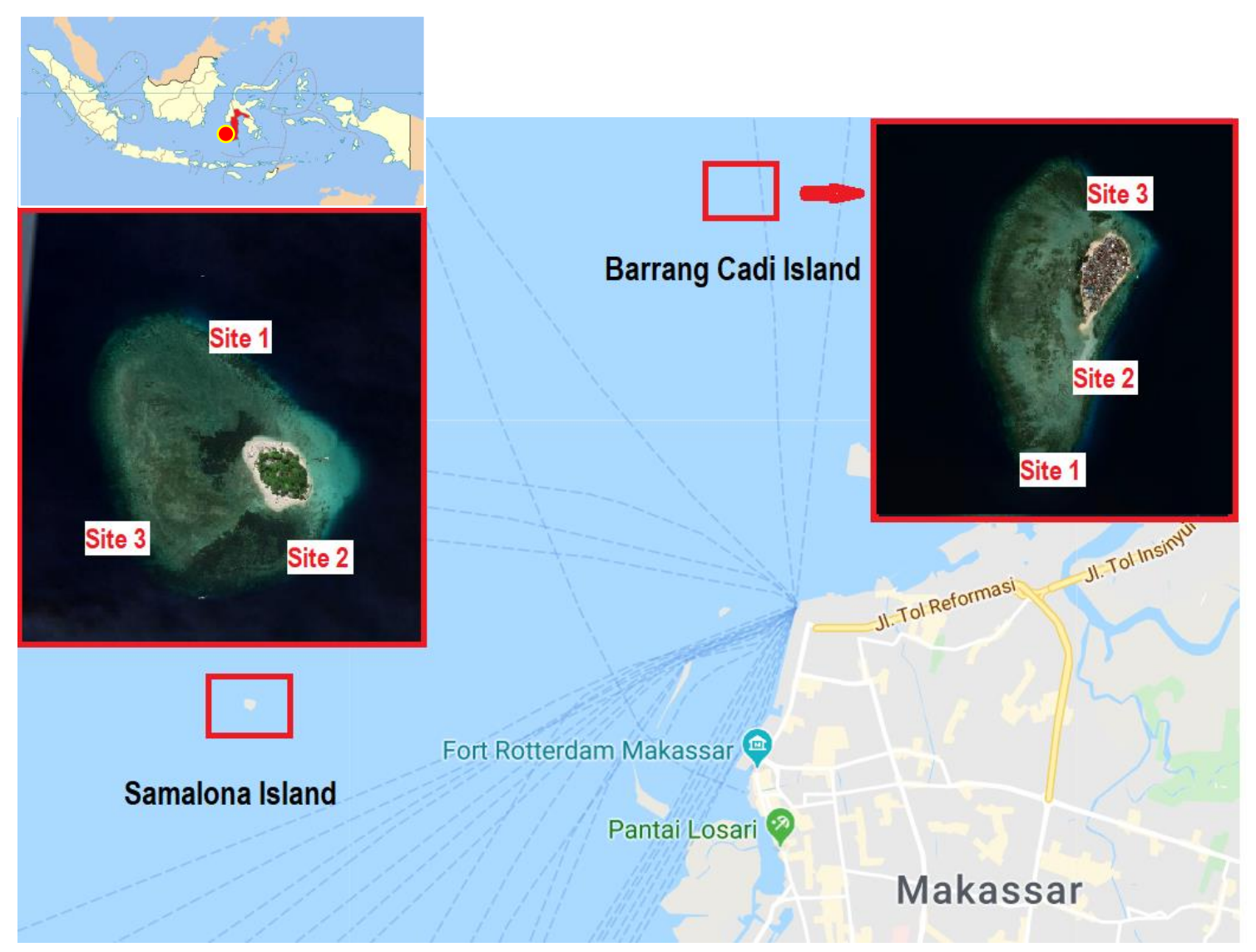

Figure 1. The collection sites of the marine invertebrates in Samalona and Barrang Caddi, Spermonde Islands, Makassar, Indonesia 


\section{Antibacterial screening}

Antibacterial activity of all isolates was confirmed using agar plug method (Balouiri, Sadiki and Ibnsouda 2016; Sibero et al. 2019) against vibriosis agents such as Vibrio harveyi, V. parahaemolyticus, and V. vulnificus. The pathogens were recultured on nutrient agar medium for 24 $\mathrm{h}$ at $32{ }^{\circ} \mathrm{C}$ whereas, the pure isolates were cultivated on agar medium for 7 days at room temperature $\left(27^{\circ} \mathrm{C}\right)$ before performed the assay. In antibacterial assay, the pathogens were diluted into nutrient broth and its density was set up to 0.5 McFarland standards. Testing agar media were prepared by inoculating the pathogen solution onto the surface of nutrient agar media using a sterilized cotton swab. Then, approximately $1 \mathrm{~cm}^{2}$ of fungal culture with its agar were cut and plugged onto the inoculated testing agar. The testing media were incubated at $32{ }^{\circ} \mathrm{C}$ to maximize the pathogen's growth for $24 \mathrm{~h}$. Further, the formation of clear zone around the agar plugs indicated the antibacterial activity of the prospective isolates.

\section{Fungal identification}

Molecular identification of prospective isolates was carried out by amplifying the internal transcribed spacer (ITS) as the finger print region for fungal barcoding using polymerase chain reaction (PCR) thermal cycler. The ingredient of PCR mix was $12.5 \mu \mathrm{L}$ of GoTaq Green Master mix from Promega Corporation, $1 \mu \mathrm{L}$ of ITS1 (5'TCC GTA GGT GAA CCT GCG G-3') as forward primer, $1 \mu \mathrm{L}$ of ITS4 (5'-TCC TCC GCT TAT TGA TAT GC-3') as reverse primer from Macrogen, $9.5 \mu \mathrm{L}$ of $\mathrm{ddH}_{2} \mathrm{O}$ and 1 $\mu \mathrm{L}$ of DNA template Trianto et al. (2018) and Sibero et al. (2018). PCR condition was denaturation at $95^{\circ} \mathrm{C}$ for $1 \mathrm{~min}$; 34 cycles of denaturation at $95{ }^{\circ} \mathrm{C}$ for $3 \mathrm{~min}$, annealing at $56.1{ }^{\circ} \mathrm{C}$ for $1 \mathrm{~min}$, extension at $72{ }^{\circ} \mathrm{C}$ for $1 \mathrm{~min}$; final extension at $72{ }^{\circ} \mathrm{C}$ for $7 \mathrm{~min}$ and cooling at $4{ }^{\circ} \mathrm{C}$ until recovery of the samples. The PCR product was sent to Genetika Science for sequencing. The sequences results were compared to GenBank database in The National Center for Biotechnology Information (NCBI) using the Basic Local Alignment Search Tool (BLAST). The phylogenetic tree was reconstructed using MEGA 6.

\section{RESULTS AND DISCUSSION}

Samalona and Barrang Caddi Islands in Spermonde archipelago, Makassar were chosen as research sites due to the diversity of marine invertebrates. Early study of de Voogd et al. (De Voogd et al. 2006) reported that the sponge diversity in Spermonde archipelago which was dominated by Amphimedon, Callyspongia, Chalinula, Clathria, Haliclona, Hyrtios, and Petrosia. Further study reported the finding of more genus and species such as Aaptos, Agelas, Aplysina, Cliona, Dysdea, Haliclona, and Xestospongia in these areas (Haris et al. 2014). In addition, another invertebrate such as ascidian has been well studied in the same location by Litaay et al. (Litaay 2018; Litaay et al. 2018). The reports mentioned the species diversity of the ascidian in Spermonde archipelago was influenced by

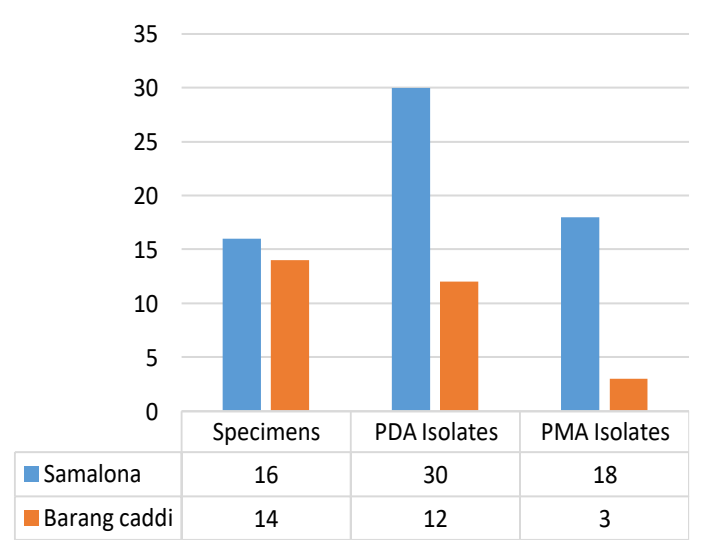

Figure 2. Invertebrate-associated fungi from Samalona and Barang Caddi, Spermonde Archipelago, South Sulawesi, Indonesia in different isolation media

the environmental conditions to support its survival ability. Moreover, Polycarpa and Didemnum were the most dominant ascidian. This study successfully collected 30 marine invertebrates from Samalona and Barrang Caddi Islands that were expected to harbor associated fungi, therefore fungal isolation could be performed. Figure 2 shows the abundance of the fungal isolates that grown in PDA and PMA media.

Several studies used different cultivation medium to obtain more diverse fungal species. Xu et al. ( 2018a) performed fungal isolation from deep-sea sediment with 6 cultivation media, for instance, Malt Extract Agar (MEA), Czapek Dox Agar (CDA), Corn Meal Agar (CMA), Sabaurauds dextrose agar (SDA), Yeast extract-malt Agar (YMA) and Potato Dextrose Agar (PDA). The study found that YMA was the best medium because it resulted in 30 isolates with 9 species. On the other hand, another study stated that PDA resulted in higher fungal abundance than other media such as MEA, CDA, SDA, CMA, PDA, YMA, Martin medium (MAR), and Murashige and Skoog medium (MSA) that were used to isolate scleractinian coralassociated fungi (Xu et al. 2018b). This study utilized PDA as the representatives of rich nutrient media because previous studies indicated this media is one of the proposed media for fungal isolation from marine environment. As expected, as a rich nutrient medium, PDA harbored number of isolate because it provided the nutrients that are needed by the fungi to grow and sporulate. PDA media gave 42 isolates whereas only 21 isolates were isolated from PMA. Certain substances such as carbon source, nitrogen source, and trace minerals are noted very essentially to influence the abundance of the cultivable fungi during the isolation (Sharma and Pandey 2010; Muggia et al. 2017). Furthermore, a similar study which was done by Bovio et al. (2019) reported a similar result. The poor marine agar (PMA) could not provide any nutrients that supported fungal growth, therefore, only a few fungal taxa can grow on it. In addition, aside of nutrient in cultivation media, several factors that influence the number of fungal taxa 
were isolation technique, tissue structure, the host, habitat, incubation temperature, and the metabolite that was produced by the host (Henríquez et al. 2014; Calabon et al. 2018; Xu et al. 2018; Bovio et al. 2019; Sibero et al. 2019). In order to obtain prospective isolate which produces antibacterial compound, a screening using plug media against vibriosis agent was performed. The result of antibacterial screening activity is shown in Figure 3.

Plug method was carried out to screen the antibacterial potential of all isolates. Basically, the plug method relies on the metabolites that are secreted into the cultivation agar medium during the fungal growth, afterward metabolites scatter onto the test agar which has been inoculated by the pathogen. Künzler (2018) stated that fungi are used to secrete effectors to inhibit or kill microbial competitors, while the effectors against metazoan predators are produced and stored within the cell. The production of antibacterial substances will be expressed by the presence of inhibition zone because the bacteria around the agar plug are killed by the secreted metabolite (Balouiri et al. 2016; Sibero et al. 2018, 2019). Table 1 shows that plenty of fungi exhibited antibacterial property against vibriosis agents. The antibacterial activity of the isolates was distinguished as bactericidal and bacteriostatic. Bactericidal activity is indicated by the formation of permanent inhibition zone because the metabolite kills the bacteria, thus the inhibition zone is not recovered by the bacterial growth. Vice versa, bacteriostatic activity only inhibited the growth of the pathogens, therefore the diameter of inhibition zone will be decreased by the time (Nemeth et al. 2015). Interestingly, fungi isolated using PDA were not as potent as fungi isolated using PMA (Figure 3). Among 40 isolates from rich nutrient media, only 4 isolates performed antibacterial against $V$. harveyi, 4 isolates inhibited $V$. parahaemolyticus and 16 isolates for $V$. vulnificus, whereas all isolates from PMA exhibited antibacterial activity against all vibriosis agents. It is never been reported the fungal secondary metabolite was produced in a PMA which contained only seawater and agar. This fact gives another point of view on fungal biological activity.

The ability of all isolates from PMA might be induced by the nutrition scarcity in the medium (Demain 1998; Ruiz et al. 2010). Nutrient availability such as carbon and nitrogen influence the sporulation process and its natural product productions. Several works have proven that the source of carbon and nitrogen greatly impacts the antibacterial activity of fungi (Bhattacharyya and Jha 2011; Jain and Gupta 2012; Rani and Jain 2017). This study obtained an interesting result that fungi producing metabolite on PMA strongly inhibited vibriosis agents. However, further study is strongly needed to understand the produced metabolites.

\section{Molecular identification}

The molecular analyses as shown in Figure 4, reveals that the most active isolates belong to the genus Aspergillus i.e. A. flavus (3 isolates), A. orizae (1 isolate), and $A$. aculetus ( 1 isolate), while other identified isolates are Talaromyces minioluteus (1), Hypocrea jecorina (1), Gliomastix murorum, Myrothecium inundatum (1), and Curvularia affinis (1). Aspergillus is a genus consisting of a few hundred mould species found in various climates worldwide. Aspergillus flavus is a saprotrophic and pathogenic [1] fungus with a cosmopolitan distribution. It is best known for its colonization on cereal grains, legumes, and tree nuts. Postharvest rot typically develops during harvest, storage, and/or transit. A. flavus infections can occur while hosts are still in the field (preharvest) without any symptoms (dormancy) until postharvest storage and/or transport. Many strains of Aspergillus produce toxic compounds known as mycotoxins in high quantities. A noncarcinogenic and aflatoxin-free Aspergillus flavus strain AF36 is used as an active ingredient in pesticides which was used as commercial biocontrol in cotton and corn to reduce aflatoxin exposure.

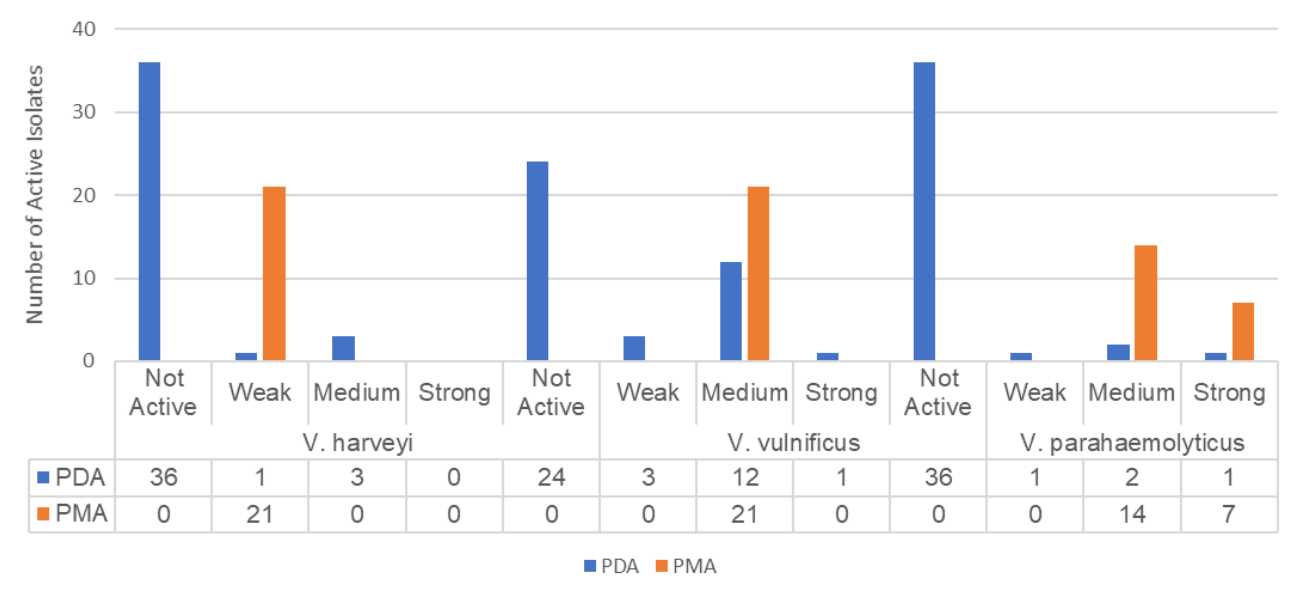

Figure 3. The active isolates from PDA media and PMA media against the vibrio 


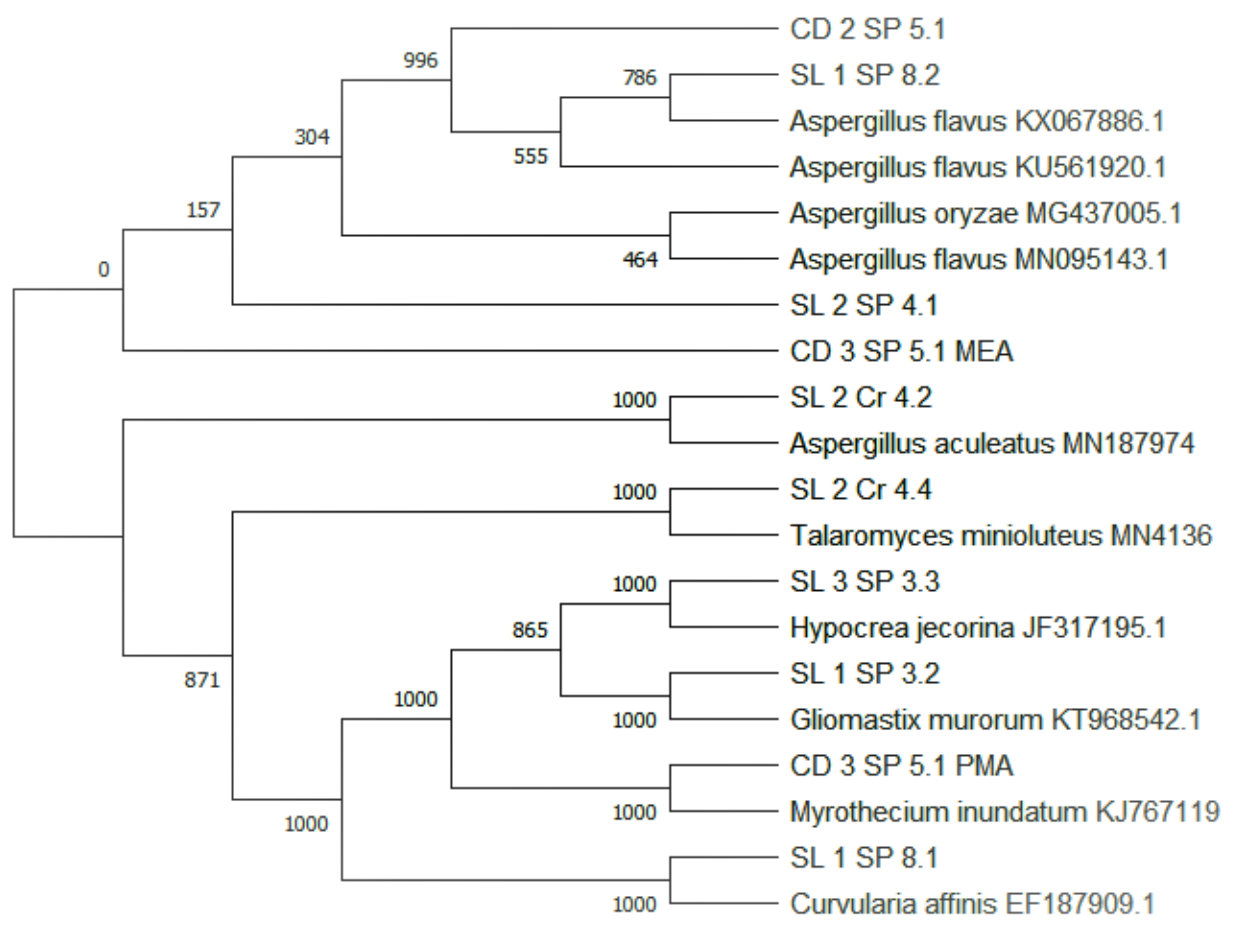

Figure 4. Phylogenetic tree of active fungal isolates from Samalona dan Barrang Cadi Islands, Spermonde Islands, Makassar, Indonesia

Aspergillus oryzae is a filamentous fungus used in Japan to ferment soybeans for making soy sauce and fermented bean paste (including miso), and also to saccharify rice, other grains, and potatoes in the making of alcoholic beverages such as sake and shōchū. A. oryzae is also used for the production of rice vinegar and for production of resveratrol from its glucoside piceid (Wang et al. 2007).

A. aculeatus belongs to the group of black Aspergilli which are important industrial workhorses. A. aculeatus is considered to be a ubiquitous species that could be usually isolated from rotting fruits and soil. Modern biochemical and molecular identification techniques are helpful in the identification of Aspergillus isolates, such as black-spored Aspergillus species may have significant variations in their morphological and physiological characteristics. Aspergillus can rapidly degrade cell walls of plants they infect, and isolates of $A$. aculeatus have been used to produce a number of important industrial enzymes, including cellulases, hemicellulases, and proteases. These by-products are broadly used in the food and feed industries. Due to its industrial value, the biochemical and catalytic properties of several hydrolases from A. aculeatus have been extensively studied. Also, structural studies using X-ray crystallography have been carried out on several polysaccharide degrading enzymes from Aspergillus aculeatus.

Talaromyces minioluteus is an important fungal genus because of its ubiquity which was isolated from soil, plants, sponges, and foods. Some of the species are heat resistant.
Some of the species are famous because of their enzymes applicable in the synthesis of saccharides, preparation of chiral building blocks or biotransformations, and for its application in pest biocontrol. Many of its species are used in food and agricultural production (Jie et al. 2016). Hypocrea jecorina, The pantropical ascomycete Hypocrea jecorina (anamorph Trichoderma reesei) is known as an industrial producer of cellulolytic enzymes (Lynd et al. 2002). The mechanism, which H. induces jecorina cellulases has remained enigmatic, especially since cellulases are only formed upon induction but the natural inducer (=cellulose) cannot pass the cell wall and plasma membrane and thus cannot enter the cell (Schmoll and Kubicek 2005). Curvularia affinis is an ecologically and economically important genus and is known as an anamorph of Cochliobolus Drechs. Pleosporales (class Dothideomycetes, Ascomycota). The approximately 54 species are included in the genus and are usually known as subtropical and tropical facultative parasites on herbaceous plants (Yanagihara et al. 2010).

\section{ACKNOWLEDGEMENTS}

Thank Directorate General of Strengthening Research and Social Service Ristek DIKTI, Indonesia for the research grant through Fundamental research grant with the contract number: 201-01/UN7.P4.3 /PP/2019. 


\section{REFERENCES}

Balouiri M, Sadiki M, Ibnsouda SK. 2016. Methods for in vitro evaluating antimicrobial activity: A review. J Pharm Anal 6 (2): 71-79. DOI: 10.1016/j.jpha.2015.11.005.

Bhattacharyya PN, Jha DK. 2011. Optimization of cultural condition affecting growth and improved bioactive metabolite production by a subsurface Aspergillus strain TSF 146. Intl J Appl Biol Pharm Technol 2 (4): 133-143.

Bovio E, Garzoli L, Poli A, Luganini A, Villa P, Musumeci R, McCormack GP, Cocuzza CE, Gribaudo G, Mehiri M, Varese GC 2019. Marine Fungi from the sponge grantia compressa: biodiversity, chemodiversity, and biotechnological potential. Mar Drugs 17 (4) DOI: $10.3390 / \mathrm{md} 17040220$.

Calabon MS, Sadaba RB, Campos WL. 2018. Fungal diversity of mangrove-associated sponges from New Washington, Aklan, Philippines. Mycology. DOI: 10.1080/21501203.2018.1518934.

Carroll AR, Copp BR, Davis RA, Keyzers RA, Prinsep MR. 2019, Marine natural products. Nat Prod Rep 36 (1): 122-173. DOI: 10.1039/c8np00092a

Chen L, Hu JS, Xu JL, Shao CL, Wang GY. 2018. Biological and chemical diversity of ascidian-associated microorganisms. Mar Drugs 16 (10): 1-33. DOI: $10.3390 / \mathrm{md} 16100362$.

De Voogd NJ, Cleary DFR, Hoeksema BW, Noor A, Van Soest RWM 2006. Sponge beta diversity in the Spermonde Archipelago, SW Sulawesi, Indonesia. Mar Ecol Prog Ser 309: 131-142. DOI: 10.3354/meps309131.

Demain AL. 1998. Induction of microbial secondary metabolism. Int Microbiol 1 (4): 259-264. DOI: 10.2436/im.v1i4.26

Grossart HP, Wurzbacher C, James TY, Kagami M. 2016. Discovery of dark matter fungi in aquatic ecosystems demands a reappraisal of the phylogeny and ecology of zoosporic fungi. Fungal Ecol 19: 28-38. DOI: 10.1016/j.funeco.2015.06.004.

Haris A, Werorilangi S, Gosalam S, Masâud,A. 2014. Komposisi jeni dan kepadatan sponge (Porifera: Demospongiae) di Kepulauan Spermonde Kota Makassar. J Biota 19 (1). DOI: 10.24002/biota.v19i1.453. [Indonesian]

Hassett BT, Gradinger R. 2016. Chytrids dominate arctic marine fungal communities. Environ Microbiol 18 (6): 2001-2009. DOI 10.1111/1462-2920.13216.

Henríquez M, Vergara K, Norambuena J, Beiza A, Maza F, Ubilla P, Araya I, Chávez R, San-Martín A, Darias J, Darias MJ, Vaca I. 2014 Diversity of cultivable fungi associated with Antarctic marine sponges and screening for their antimicrobial, antitumoral and antioxidant potential. World J Microbiol Biotechnol 30 (1): 65-76. DOI: $10.1007 / \mathrm{s} 11274-013-1418-\mathrm{x}$

Imhoff JF. 2016. Natural products from marine fungi-still an underrepresented resource. Mar Drugs 14 (1). DOI: 10.3390/md14010019.

Jain P, Gupta S. 2012. Effect of carbon and nitrogen sources on antimicrobial metabolite production by endophytic fungus Penicillium sp. against human pathogens. J Pharm Res 5 (8): 4325-4328.

Jie MZ, Jiang LC, Di YSD, Crews P. 2016. The bioactive secondary metabolites from Talaromyces species. Nat Prod Bioprospecting 6 (1): 1-24. DOI: 10.1007/s13659-015-0081-3.

Künzler M. 2018. How fungi defend themselves against microbial competitors and animal predators. PLoS Pathogens. DOI: 10.1371/journal.ppat.1007184

Lindequist U. 2016. Marine-derived pharmaceuticals-challenges and opportunities. Biomolecules Ther 24 (6): 561-571. DOI 10.4062/biomolther.2016.181.

Litaay M. 2018. Marine tunicates from Sangkarang Archipelago Indonesia: Recent finding and bio-prospecting. J Phys: Conf Ser 979 (1). DOI: 10.1088/1742-6596/979/1/012003.

Litaay M, Santosa S, Johannes E, Agus R, Moka W, Dhewi J, Tanjung D. 2018. Biodiversity of marine tunicates in Samalona waters, Sangkarang Archipelago, Indonesia. Spermonde 4 (1): 26-31.

Lynd LR, Weimer PJ, van Zyl WH, et al. 2002. Microbial cellulose utilization: fundamentals and biotechnology. Microbiol Mol Biol Rev 66: 506-577.

Muggia L, Kopun T, Grube M. 2017. Effects of growth media on the diversity of culturable fungi from lichens. Molecules 22 (5): 1-22. DOI: $10.3390 /$ molecules22050824.

Nemeth J, Oesch G, Kuster SP. 2015. Bacteriostatic versus bactericida antibiotics for patients with serious bacterial infections: systematic review and meta-analysis. J Antimicrob Chemother 70: 382-395.
DOI: $10.1093 / \mathrm{jac} / \mathrm{dku} 379$.

Pereira F. 2019. Have marine natural product drug discovery efforts been productive and how can we improve their efficiency? Expert Opin Drug Discov 14 (8): 717-722. DOI: 10.1080/17460441.2019.1604675.

Pham JV, Yilma MA, Feliz A, Majid MT, Maffetone N, Walker JR, Kim E, Cho HJ, Reynolds JM, Song MC, Park SR, Yoon YJ. 2019. A review of the microbial production of bioactive natural products and biologics. Front Microbiol 10: 1-27. DOI: 10.3389/fmicb.2019.01404.

Rani N. Jain P. 2017. Isolation of antimicrobial compound producing fungi from the rhizospheric soil of the medicinal plant Azadirachta indica. J Chem Pharm Res 9 (9): 265-270.

Ruiz B, Chávez A, Forero A, García-Huante Y, Romero A, Sanchez M, Rocha D, Sanchez B, Rodríguez-Sanoja R, Sánchez S, Langley E. 2010. Production of microbial secondary metabolites: Regulation by the carbon source. Crit Rev Microbiol 36 (2): 146-167. DOI: 10.3109/10408410903489576

Schmoll M, Kubicek ÆCP. 2005. ooc1, a unique gene expressed only during growth of Hypocrea jecorina (anamorph : Trichoderma reesei) on cellulose. Curr Genet 48 (2): 126-133. DOI: 10.1007/s00294-0050585-1.

Sharma G, Pandey RR. 2010. Influence of culture media on growth, colony character, and sporulation of fungi isolated from decaying vegetable wastes. J Yeast Fungal Res 1 (8): 157-164.

Sibero MT, Igarashi Y, Radjasa OK, Sabdono A, Trianto A, Zilda DS, Wijaya YJ. 2019. Sponge-associated fungi from a mangrove habitat in Indonesia: species composition, antimicrobial activity, enzyme screening and bioactive profiling. Intl Aquat Res 11 (2): 173-186. DOI: $10.1007 / \mathrm{s} 40071-019-0227-8$

Sibero MT, Radjasa OK, Sabdono A, Trianto A, Triningsih DW, Hutagaol ID. 2018. Antibacterial activity of Indonesian sponge-associated fungi against clinical pathogenic multidrug-resistant bacteria. J Appl Pharm Sci 8 (2): 088-094. DOI: 10.7324/JAPS.2018.8214.

Sibero MT, Triningsih DW, Radjasa OK, Sabdono A, Trianto A, Priyani N, Prastyo A. 2018. Antimicrobial activity of sponge-associated fungi from Pandang Island, North Sumatera against clinical pathogenic microorganisms. Asian J Microbiol Biotechnol Environ Sci 20 (1): 142-149.

Tarman K, Lindequist U, Wende K, Porzel A, Arnold N, Wessjohann LA. 2011. Isolation of a new natural product and cytotoxic and antimicrobial activities of extracts from fungi of Indonesian marine habitats. Mar Drugs 9 (3): 294-306. DOI: 10.3390/md9030294.

Tarman K, Palm GJ, Porzel A, Merzweiler K, Arnold N, Wessjohann LA, Unterseher M, Lindequist U. 2012. Helicascolide C, a new lactone from an Indonesian marine algicolous strain of Daldinia eschscholzii (Xylariaceae, Ascomycota). Phytochem Lett 5 (1): 83-86. DOI: 10.1016/j.phytol.2011.10.006

Trianto A, Sabdono A, Rochaddi B, Triningsih DW. 2017. Exploration of marine sponges-associated fungi producing antifungal. Asian J Microbiol Biotechnol Environ Sci 19 (3): 588-593.

Trianto A, Sabdono A, Rochaddi B, Triningsih DW, Zilda DS. 2018. Identification sponges-associated fungi from Karimunjawa National Park. IOP Conf Ser: Earth Environ Sci 116 (1). DOI: 10.1088/17551315/116/1/012098.

Wang H, Liu L, Guo YX, Dong YS, Zhang DJ, Xiu ZL. 2007. Biotransformation of piceid in Polygonum cuspidatum to resveratrol by Aspergillus oryzae. Appl Microbiol Biotechnol 75 (4): 763-768.

Xu L, Meng W, Cao C, Wang J, Shan W, Wang Q. 2015. Antibacterial and antifungal compounds from marine fungi. Mar Drugs 13: 34793513. DOI: $10.3390 / \mathrm{md} 13063479$

Xu W, Guo S, Gong L, Alias SA, Pang KL, Luo ZH. 2018. Phylogenetic survey and antimicrobial activity of cultivable fungi associated with five scleractinian coral species in the South China Sea. Bot Mar 61 (1): 75-84. DOI: 10.1515/bot-2017-0005.

Xu W, Guo S, Gong LF, He G, Pang KL, Luo ZH. 2018. Cultivable fungal diversity in deep-sea sediment of the East Pacific Ocean. $\begin{array}{lllll}\text { Geomicrobiol } & \text { J } & 35 & \text { (9): } & \text { 790-797. }\end{array}$ 10.1080/01490451.2018.1473531.

Yanagihara M, Kawasaki M, Ishizaki H, Anzawa K. 2010. Tiny keratotic brown lesions on the interdigital web between the toes of a healthy man caused by Curvularia species infection and a review of cutaneous Curvularia Infect 51 (3): 224-233. DOI: 10.1007/s10267-009-0030-2.

Zhou Y, Debbab A, Wray V, Lin W, Schulz B, Trepos R, Pile C, Hellio C, Proksch P, Aly AH. 2014. Marine bacterial inhibitors from the sponge-derived fungus Aspergillus sp. Tetrahedron Lett 55 (17): 2789-2792. DOI: 10.1016/j.tetlet.2014.02.062. 
BIODIVERSITAS

Volume 21, Number 1, January 2020

Pages: 407-412
ISSN: 1412-033X

E-ISSN: 2085-4722

DOI: $10.13057 /$ biodiv/d210147 